\title{
An overview of the management of muscle pain and injuries
}

\author{
O Babarinde, H Ismail, N Schellack* \\ School of Pharmacy, Faculty of Health Sciences, Sefako Makgatho Health Sciences University \\ *Corresponding author, email: natalie.schellack@smu.ac.za
}

\begin{abstract}
Sport injuries and muscle pain can occur as a result of engagement in exercise and or organized sporting activities. These injuries affect all age groups and gender. The most common types of sporting activities known to cause these injuries include jogging, cycling, volleyball, swimming and heavy weight lifting. Lack of warm-ups before participating in sporting activity, overtraining and or excessive exposure to these physical activities may increase risk of causing injuries. These factors are categorized as extrinsic factors. Intrinsic factors that may lead to sport injuries or may precipitate these injuries are age, previous injuries and level of flexibility. The most common type of injuries seen are sprains and strains. These injuries are accompanied with pain, swelling and redness of injured area. Non-pharmacological and pharmacological management are available for the effective management of these injuries. Pain may vary from mild to severe depending on the severity of injury. These varying types of pain can be managed optimally using non-narcotics such as paracetamol and non-steroidal anti-inflammatory (NSAIDs) like ibuprofen. When pain is categorized as moderated to severe, narcotics may be prescribed and administered.
\end{abstract}

Keywords: sport injuries, sprains, strains, PRICE, TENS, narcotics, non-narcotics, NSAIDs

\section{Key Summary Points}

- Sports injuries are injuries that occur during exercise or sporting activities.

- These injuries can occur as a result of intrinsic or extrinsic factors.

- These injuries can be classified as acute or chronic and further classified as microtrauma or macrotrauma.

- The most common types of sport injuries include sprain, strain, groin pull, knee injury.

- Optimal management includes non-pharmacological management (PRICE, TEN) and pharmacological management (analgesic, narcotics, non-narcotics).

\section{Introduction}

Participation in exercise and sporting activities offers many benefits and should be encouraged. It assists with weight management, maintaining overall health, improving a persons' wellbeing and it provides psychological benefits. However, these activities are associated with risks and complications such as sport injuries (Figure 1).

The most common types of sport activities associated with sporting injuries are $^{2}$ :

- Running or jogging

- Contact sports - rugby, soccer, hockey and boxing

- Racket sports - tennis, badminton

- Volleyball
- Basketball

- Heavy weight lifting

- Cycling

- Golfing

- Swimming

\section{Causes of sport injuries}

The term sports injuries is used to describe any injury that occurs during exercise and sporting activities ${ }^{1}$. Sporting injuries can result from:

- Accidents while playing sport

- Insufficient warming up

- Poor training processes

- Lack of equipment or proper equipment(e.g. inappropriate boxing gloves)

\section{Risk of sports injuries}

There are many different types of sports injuries that can occur. The most common include sprains, tears, dislocations and fractures (Figure 1). ${ }^{3}$

Sports injuries can occur due to many different factors. These factors include intrinsic and extrinsic factors (Figure 2 and 3). ${ }^{3}$ Intrinsic factors refer to factors that makes a person more vulnerable to getting injured. Extrinsic factors include 
environmental factors that affect how a sporting activity is done. ${ }^{3,4}$

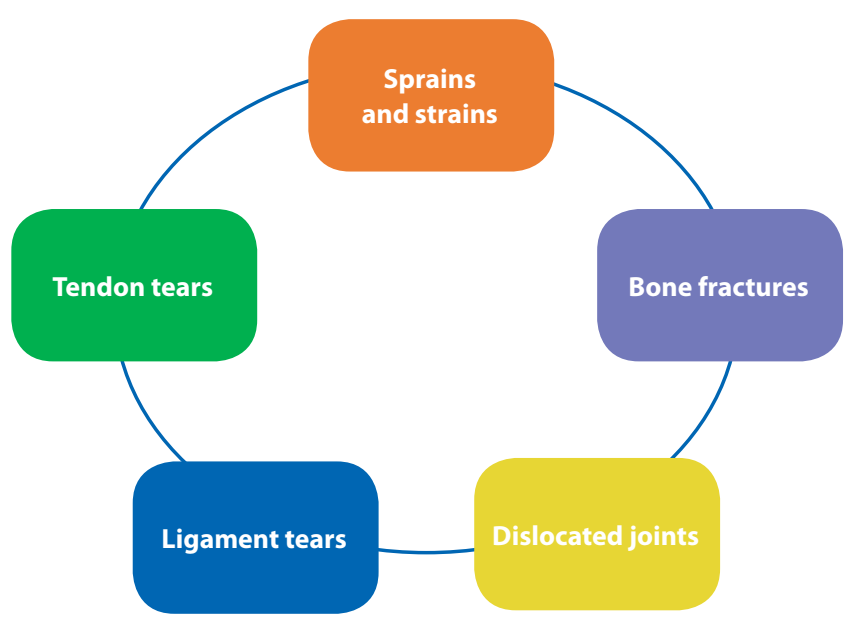

Figure 1: The most common types of sports injuries

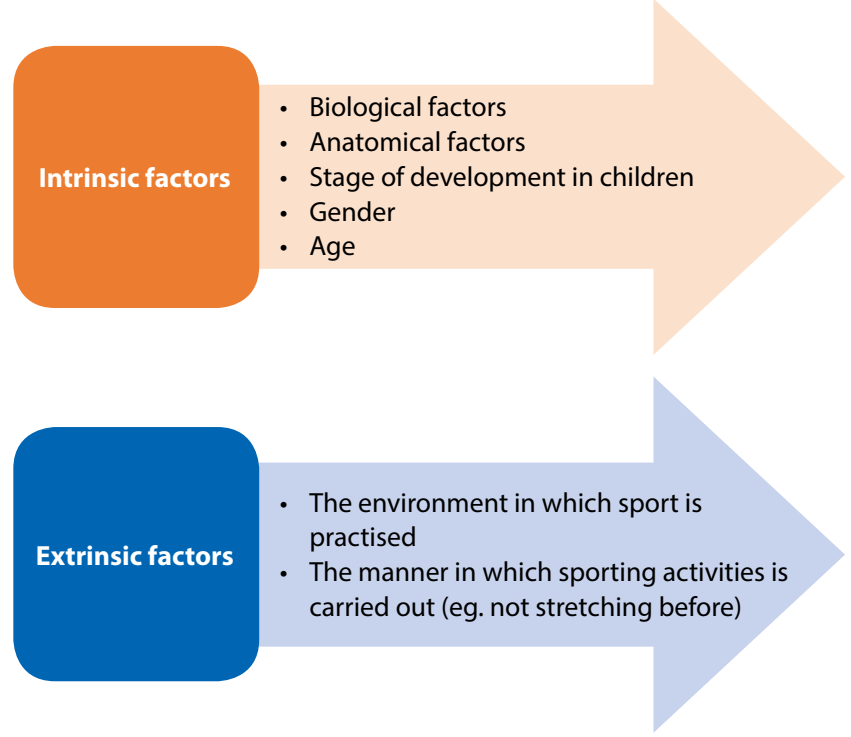

Figure 2: Risk factors of sports injuries

A person carries an intrinsic predisposition to getting injured. After the person is exposed to an extrinsic risk (e.g. not wearing the correct shoes) an injury will occur. ${ }^{3}$

\section{Classification of sports injuries}

Sports injuries are generally classified as acute or traumatic AND chronic/overuse regardless of the affected structure. ${ }^{4}$ Acute or traumatic injuries include sprains, cuts, fractures and concussions. These injuries have a sudden onset and heal relatively quickly. ${ }^{4} \mathrm{Chronic}$ injuries are a result of overusing one area of the body while playing sport. It takes a long period of time to develop a chronic injury and healing takes much longer than an acute injury. ${ }^{4}$ The signs and symptoms of acute and chronic injuries are listed in the Table below

\begin{tabular}{|c|c|}
\hline Acute Injury & Chronic Injury \\
\hline Sudden onset of pain & Swelling at site of injury \\
\hline Severe pain & Dull uncomfortable pain at rest \\
\hline $\begin{array}{l}\text { Bleeding if there is a cut or } \\
\text { grazing }\end{array}$ & Pain when performing activity \\
\hline Visible discoloration or bruising & $\begin{array}{l}\text { Inability to move joint through } \\
\text { its full range of movement }\end{array}$ \\
\hline \multicolumn{2}{|l|}{ Swelling } \\
\hline \multicolumn{2}{|l|}{ Tenderness } \\
\hline \multicolumn{2}{|l|}{$\begin{array}{l}\text { Inability to put weight onto a } \\
\text { lower limb }\end{array}$} \\
\hline \multicolumn{2}{|l|}{ Weakness of the limb or joint } \\
\hline $\begin{array}{l}\text { Inability to move joint through } \\
\text { its full range of movement }\end{array}$ & \\
\hline
\end{tabular}

Sport injuries may also be classified as mircotraumas and macrotraumas. ${ }^{6}$

- Microtraumas result from constant injury to a certain part of the body or overuse of a certain muscle, joint, tissue, etc. Further to this they include tears in fibre and connective tissues as well as strains and overstretched tendons.

- Macrotraumas occur with a single traumatic event and include cuts, bruises, sprains and fractures followed by swelling and loss of function. ${ }^{6}$

\section{Types of sports injuries}

\section{Sprains}

Sprains are caused when there is a stretch or tear of the ligament. Sprains generally happen when there is a hard knock to the body causing trauma to the ligament. ${ }^{7}$

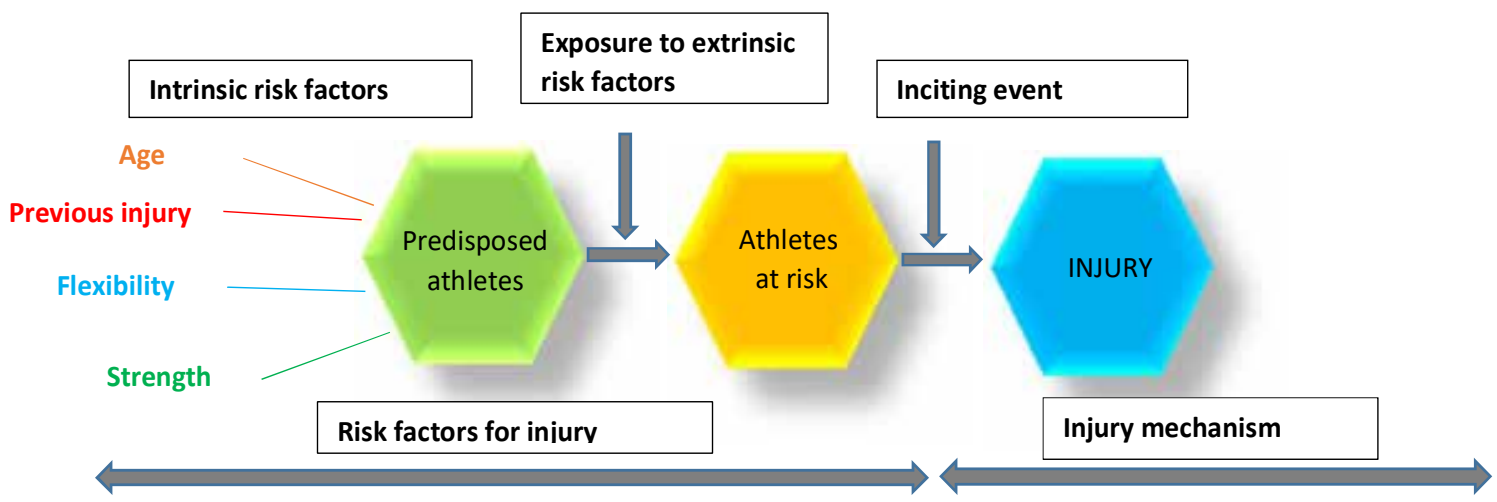


There are different degrees of sprains ranking from a partial tear to a severe tear and this is classified in Table 2.

Table 2: Classification of sprains

\begin{tabular}{ll}
\hline Degree of sprain & \\
\hline Degree 1 & $\begin{array}{l}\text { Partial/slight tear } \\
\text { Joint is still stable } \\
\text { Little pain and swelling }\end{array}$ \\
Degree 2 & $\begin{array}{l}\text { Moderate tear } \\
\text { Joint is moderately unstable } \\
\text { Moderate to severe pain or swelling }\end{array}$ \\
Degree 3 & $\begin{array}{l}\text { Complete rupture } \\
\text { Joint is completely unstable } \\
\text { Severe pain and swelling } \\
\text { Generally other tissues are also affected }\end{array}$ \\
\hline
\end{tabular}

\section{Strains}

A strain is most commonly known as a 'muscle pull' or 'torn tendon'. A strain occurs when there is damage to a muscle fibre or to a tendon.?

Just like sprains, there are also different degrees of muscle strains ranging from a first degree or mild strain to a third degree or most severe strain (Table 3 ).

Table 3: Classification of strains

\begin{tabular}{ll}
\hline Degree of strain & \\
\hline Degree 1 & $\begin{array}{l}\text { Partial/ slight tear } \\
\text { Full range of motion accompanied by pain } \\
\text { Tenderness at sight of tear }\end{array}$ \\
Degree 2 & $\begin{array}{l}\text { Moderate tear to the tissue or tendon } \\
\text { Limited movement } \\
\text { Moderate to severe pain } \\
\text { Swelling and possibly depression at the site of } \\
\text { injury } \\
\text { Degree 3 }\end{array}$ \\
& $\begin{array}{l}\text { Complete tear } \\
\text { No movement } \\
\text { Exceptionally painful initially, however, it can be } \\
\text { painless after the initial injury. }\end{array}$ \\
\hline
\end{tabular}

\section{Knee injury}

Knee injuries are fairly common especially in weight bearing sports or weight training exercises. Knee injuries also range from mild injuries to severe injuries. However, a slight injury to the knee may render severe pain and limit the range of motion. The three most common knee problems encountered are: runners knee, iliotibial band syndrome and tendonitis (Figure 4). More severe injuries to the knee include damage to the bone, cartilage or ligaments. ${ }^{4}$

\section{Runners knee}

- Pain or tenderness is experianced at the front or side of the knee close to the knee cap

\section{Iliotibial band syndrome}

- Pain is experienced on the outer part of the knee

\section{Tendonitis}

- Degeneration of the tendon

Figure 4: Types of knee injuries

\section{Groin pull}

This occurs due to a continuous pushing off in a side-to-side motion, which may lead to strain of the muscles of the inner thigh or groin. This can occur in individuals who participate in sports such as, hockey, soccer, football, and baseball. ${ }^{8}$

\section{Shin Splints}

These occur on the lower legs as a radiating pain down towards the lower legs. This occurs mostly as a result of running particularly when starting a more strenuous training program such as long runs on paved roads. ${ }^{8}$

\section{Tennis elbow}

This occurs when there is a repetitive use of the elbow, for example in sports like golf and tennis which involves many swings. These swings can lead to irritation or small tears in the tendon of the elbow. This is also known as epicondylitis. This is very common in tennis and golf players and occurs more commonly in adults $30-60$ years old. ${ }^{8}$

\section{Components to effectively prevent and manage injury}

Injuries that occur during sporting activities can be prevented and managed effectively as illustrated by Figure 5 . It is important not to exclude rehabilitation of these injuries to help facilitate recovery. Rehabilitation should take place under the supervision of qualified professionals (e.g. physiotherapists) before engaging in any sport activity, to prevent risk of worsening of the original injury. ${ }^{9}$

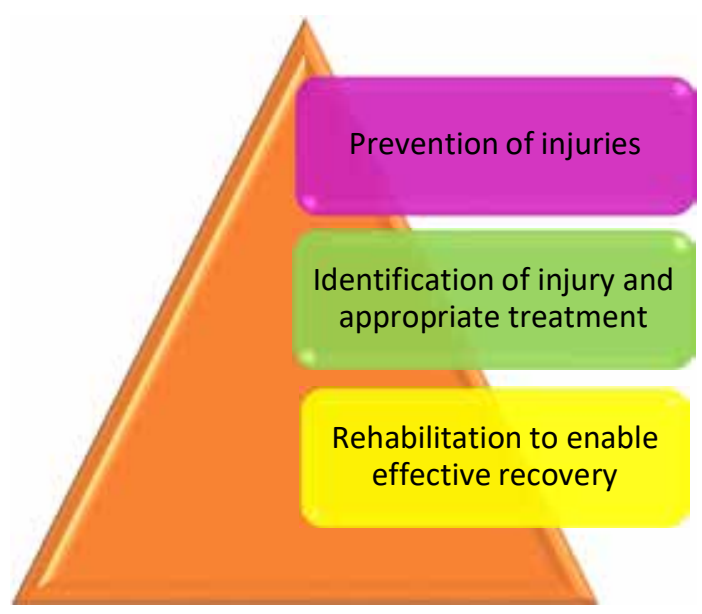

Figure 5: Components to effectively prevent and manage injury

\section{Prevention of Sport injuries}

All sport activities should begin with a gentle warm-up to prevent injuries, increase blood flow to the muscles and increase flexibility, and thereby decrease these injuries. Table 4 provides possible strategies or options on how to prevent these sport injuries. ${ }^{8,9}$ 
Table 4: Tips on how to prevent sport injuries ${ }^{9}$

- Warm up and cool down before and after sport

- Remain hydrated before, during and after sport

- Wear footwear with the appropriate support and grip

- Tape or strap vulnerable or previously injured joints and limbs

- Maintain a good level of overall fitness and muscle strength

- Don't exert yourself too far beyond your level of fitness, rest or stop when fatigued

- Slowly increase the intensity of your training routine

- Always practice the correct technique and get advice from professional trainers

- Permit satisfactory recovery time between sessions

\section{Management of sport injuries}

Typically, most of the common sports injuries are mild to moderate and can be managed effectively at home depending on the severity of the injuries, with techniques such as the PRICE therapy method (Protect from injury, Restrict activity, Ice the injured area, Compression and Elevation) which is discussed under non-pharmacological management in this article (Figure 6). It is important to educate patients that injuries may take months to heal even when managed effectively. Surgery may be required depending on severity of the injuries for example a tear in muscles or ligament. ${ }^{8}$

\section{Non-pharmacological management}

The standard golden treatment of any sports injuries especially sprains and strains is PRICE. The PRICE principle (Figure 6) helps by limiting the amount of swelling at the site of injury and preventing more injury to that specific tissue. ${ }^{7,8,10}$ Restricting activity for up to 72 hours will help with the healing process. Whist

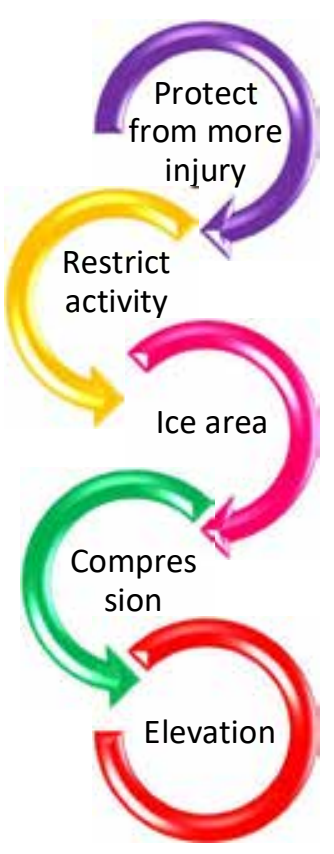

Figure 6: Management of sports injuries using the PRICE principle activity is being restricted, small muscle movements should be initiated. Icing the area helps reduce swelling and should be done for 15-20 minutes every 60-90 minutes. Compression with an elastic bandage should be considered. Raising/elevating the affected limb should be encouraged in order to reduce swelling at the site of injury. ${ }^{7,8,10}$ Different types of sports injuries generally have a different treatment approach. These treatment options are discussed below in Table 5 .

Sports injuries are commonly accompanied by muscle pain. Figure 7 below demonstrates the different methods used to relive sports injuries without using any pharmacological agents.

Treatment modalities include the following:

\section{Transcutaneous electrical stimulation (TENS)}

TENS is used to modulate pain. It is a non-invasive technique. ${ }^{11}$ TENS works by delivering electrical current through the skin in order to decrease central excitability. Thus, the nociceptive neurons in the spinal cord are inhibited, decreasing acute and chronic pain. ${ }^{12}$

\section{Acupuncture}

Acupuncture is a Chinese based treatment modality. It works by targeting specific points of the body to improve health and reduce pain. Several mechanisms have been hypothesised. Acupuncture is usually done when conventional methods of chronic pain management have failed. ${ }^{13}$

\section{Thermal modalities}

Thermal modalities is another method of managing muscle pain in sports injuries. This method uses heat. ${ }^{14}$ Temperatures used are greater than that of a normal body temperature. Treatment modalities are usually classified as superficial or deep:

- Superficial thermotherapy - depth of heat used is usually $1 \mathrm{~cm}$ deep. Modalities used include; dry heating pad, moist heating pad and paraffin baths.

- Deep thermotherapy - depth of heat used is usually between 3-5 cm deep. The device used to administer the heat includes therapeutic ultrasound.

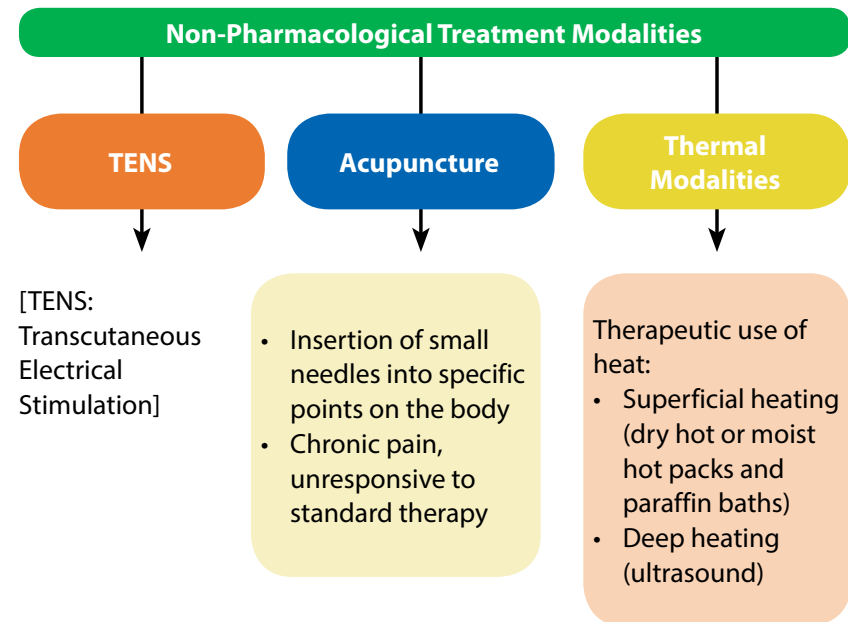


Table 5: Sport injuries and how to manage them

\begin{tabular}{|c|c|}
\hline $\begin{array}{l}\text { Types of sport } \\
\text { injuries }\end{array}$ & What to do \\
\hline Sprains & $\begin{array}{l}\text { When a patient has a sprain, it is vital } \\
\text { to exercise the body part affected. This is to } \\
\text { prevent any loss of flexibility and strength in } \\
\text { that area. In determining the kind of exercise } \\
\text { required, a consultation with a doctor or a } \\
\text { physiotherapist is advised so as not to hurt the } \\
\text { area any further while exercising. }\end{array}$ \\
\hline Strains & $\begin{array}{l}\text { Strain injuries take time to heal due to } \\
\text { the continuous stress exerted on injured } \\
\text { tissue while walking. Healing can take six } \\
\text { months to a year. Apply PRICE principle } \\
\text { as discussed above. Use over-the-counter } \\
\text { pain medication like aspirin, ibuprofen or } \\
\text { paracetamol particularly for children younger } \\
\text { than } 18 .\end{array}$ \\
\hline $\begin{array}{l}\text { Knee injuries } \\
\text { (runners knee, } \\
\text { iliotibial bond } \\
\text { syndrome, } \\
\text { tendonitis) }\end{array}$ & $\begin{array}{l}\text { It is important to be patient. These types of } \\
\text { injury take up to six weeks to heal properly. It is } \\
\text { helpful to continue low-impact exercise during } \\
\text { this time. Working out the quadriceps may also } \\
\text { relieve pain. }\end{array}$ \\
\hline Groin pull & $\begin{array}{l}\text { Best way to manage this injury is by applying } \\
\text { compression, ice, and rest. But returning to } \\
\text { full activity quickly before it has fully healed } \\
\text { may aggravate the groin pull or turn it into a } \\
\text { long-term injury. }\end{array}$ \\
\hline Shin splints & $\begin{array}{l}\text { Rest, applying ice, and over-the-counter pain } \\
\text { medicine (ibuprofen, diclofenac, paracetamol) } \\
\text { are the best way to treat this injury. }\end{array}$ \\
\hline $\begin{array}{l}\text { Tennis elbow } \\
\text { (Epicondylitis) }\end{array}$ & $\begin{array}{l}\text { Epicondylitis usually resolves itself if patients } \\
\text { stay off the tennis court or golf course for } \\
\text { a period of time until the pain resolves or } \\
\text { improves. Placing ice on the elbow may help } \\
\text { reduce pain and swelling. Use elbow straps } \\
\text { to protect and support the injured area and } \\
\text { to prevent further strain. Give non-steroidal } \\
\text { anti-inflammatory (ibuprofen, naproxen, or } \\
\text { aspirin) to assist with the management of pain } \\
\text { and swelling if necessary. }\end{array}$ \\
\hline
\end{tabular}

\section{Advice to patients}

- Non-pharmacological management and self-applied management techniques may help resolve injury, but not be efficient enough to heal the injury. Therefore it is important to ask patients to come back should the injury not heal. ${ }^{8}$ Patients should be advised to return to the health care professional, if they experience any of the signs listed below: the presence of any defects in the joint or bone, or if it is looking or moving uncharacteristically. ${ }^{8}$ Unable to tolerate weight or use the limb without serious pain or support

- Extreme swelling

- Any changes in skin colour other than mild bruising

- Not feeling any better after a few days of PRICE therapy and other self-applied management techniques.

\section{Management of muscle pain}

\section{Pharmacological management}

There are various classes of medicines that may be used in the management of sport related injuries. The most common classes include narcotic analgesics, non-narcotic analgesics and adjuvants. Optimal pain management includes using a multi-model approach to treating pain. ${ }^{15}$ This includes the use of two or more analgesics that bring about analgesia differently and that could be administered differently but still work in synergism. The multi-model approach also integrates the use of non-pharmacological with pharmacological therapy in order to treat the patient holistically. ${ }^{15}$

\section{Analgesics}

These agents are used precisely to relieve pain. Analgesics include narcotic and non-narcotic agents. These agents have different mechanisms of action and therefore exert different side effects which should be taken into consideration when prescribing/administering this agents to patients. ${ }^{16}$

\section{Non-narcotic analgesics}

There are several non-narcotic analgesic agents available on the market for the management of pain especially in children. ${ }^{15}$ These medicines include: paracetamol and non-steroidal antiinflammatory (NSAIDs) like ibuprofen. These medicines are used to manage mild to moderate pain, but when used in combination with narcotic analgesic, it can be used to manage severe pain. ${ }^{15}$

\section{Paracetamol}

Paracetamol is available over the counter for both adults and children with sport injuries. The maximum dose should not exceed $4000 \mathrm{mg}$ (4 grams) per day. When used for children, it is important to follow the recommended dosages included on the product's packaging. ${ }^{16}$ Paracetamol is the most common drug of choice due to its safety and efficacy profile. ${ }^{17}$ Paracetamol is a pro-drug which is converted to an active metabolite, cannabinoid. $\mathrm{N}$-arachidonolylphenolamide is formed following the de-acetylation of paracetamol in the brain and spinal cord to form its primary amine ( $p$-aminophenol). The involved enzyme is fatty acid amide hydrolase. $\mathrm{N}$-arachidonolylphenolamide acts as an agonist on the Transient Receptor Potential Cation Channel, which is a Subfamily V, Member 1 (TRPV1) receptor and an inhibitor of cellular anandamide uptake. This leads to an increase in the levels of endogenous cannabinoids, which inhibit cyclooxygenases in the brain. However, the definite proof that the analgesic and antipyretic effects of paracetamol are dependent on COX-inhibition is still unclear. But it is said to achieve this effect by inhibiting both isoforms of cyclooxygenase, COX-1 and COX-2 enzymes involved in prostaglandin (PG) synthesis. ${ }^{18}$ Paracetamol is available in a number of dosage forms. However, the choice of dosage form and the strength of the dose is entirely dependent on patient factors like age and severity of pain. ${ }^{19}$

\section{Non-steroidal Anti-Inflammatory Drugs (NSAIDs)}

After an injury, the body responds by activating the inflammatory cascade. Inflammatory mediators are released from the damaged tissue cells. This process initially is aimed to assist with the healing process which presents with swelling, redness, pain and tenderness. However, if inflammation is not managed it 
could slow the process of healing. In order to then reduce the inflammatory process and pain accompanied by this process, non-steroidal anti-inflammatory drug (NSAIDs) such as aspirin, ibuprofen, or naproxen sodium are recommended. ${ }^{4}$ One of the side effects includes peptic ulcer and as such contra-indicated in patients with an active peptic ulcer. Aspirin should not be used in children younger than 8 years of age.

The manner in which NSAIDs reduce inflammation is by competitively inhibiting cyclo-0xygenase (COX). COX is the enzyme needed for the conversion of arachidonic acid to prostaglandins..$^{20,21}$

The result of inhibiting COX is a reduction in prostaglandin circulation and a reduction in inflammation. NSAIDs are used as antipyretics, analgesics and anti-inflammatories. NSAIDs also exhibit similar analgesia; however, their selective inhibition of either COX-1 or COX-2 or both can guide prescribing of the one agent over the other. ${ }^{21}$
Only paracetamol and aspirin are available over-the-counter (OTC). Ibuprofen may be provided for 5 days OTC, if a patient has a post traumatic condition which presents with swelling, pain and fever. A prescription will be needed for other agents (Act 101 of 1965).

\section{Adjuvant Therapy}

Adjuvant therapy is pharmacological therapy. Adjuvant therapy is not only used to manage the side effects caused by pain medication, but can also be added on to assist patients who still have persistent pain, inflammation ${ }^{22}$ and other conditions like anxiety or depression. ${ }^{23,24}$

\section{Narcotics}

There are many narcotic products available on the market to help alleviate pain in sports injuries. ${ }^{16}$ However, the selection of a narcotic is based on personal preference. Fentanyl and morphine provide equal analgesic effects. As a healthcare provider one could

Table 6: Formulations, dosages and side-effects of various pain medications

\begin{tabular}{|c|c|c|c|}
\hline DRUG & SIDE EFFECTS & DOSAGE FORMS & DOSAGES \\
\hline Paracetamol & $\begin{array}{l}\text { Hypersensitivity skin reactions: } \\
\text { Skin rashes, pruritus and angioedema. } \\
\text { Neutropenia, thrombocytopenia } \\
\text { Nephrotoxicity } \\
\text { Hepatoxicity }\end{array}$ & $\begin{array}{l}\text { Tablets } \\
\text { Suppositories } \\
\text { Intravenous Solutions }\end{array}$ & $\begin{array}{l}1 \mathrm{~g} 6 \text { hourly } \\
\text { Maximum: } 4 \mathrm{~g} \text { per day }\end{array}$ \\
\hline Ibuprofen & $\begin{array}{l}\text { GIT: Gastric erosion ,peptic ulceration } \\
\text { Hypersensitivity reactions: Skin rashes, pruritus and } \\
\text { angioedema } \\
\text { Renal toxicity }\end{array}$ & $\begin{array}{l}\text { Tablets } \\
\text { Topical patch } \\
\text { Topical Gel } \\
\text { Oral syrup }\end{array}$ & 200-400 mg 6-8 hourly \\
\hline Indometacin & $\begin{array}{l}\text { CNS effects: Dizziness drowsiness, mental confusion, } \\
\text { headache in less than } 10 \% \text { to patients } \\
\text { Corneal deposits }\end{array}$ & Capsules & $25-50$ mg 6-8 hourly \\
\hline Ketaprofen & $\begin{array}{l}\text { GIT: Gastric erosion , peptic ulceration } \\
\text { Hypersensitivity reactions: Skin rashes, pruritus and } \\
\text { angioedema } \\
\text { Renal toxicity }\end{array}$ & tablets & 200 mg daily with meals \\
\hline Diclofenac & $\begin{array}{l}\text { GIT: Gastric erosion , peptic ulceration } \\
\text { Hypersensitivity reactions: Skin rashes, pruritus and } \\
\text { angioedema } \\
\text { Renal toxicity }\end{array}$ & $\begin{array}{l}\text { Tablets } \\
\text { Intramuscular Injection } \\
\text { Topical Gel } \\
\text { Suppositories } \\
\text { Topical patch }\end{array}$ & $\begin{array}{l}\text { Oral: } 25-50 \text { mg } 8 \text { hourly, to Maximum: } \\
150 \text { mg/day } \\
\text { Intramuscular: } 75 \mathrm{mg} 12 \text { hourly, } \\
\text { maximum of } 150 \mathrm{mg} / \text { day for } 2 \text { days only } \\
\text { Suppositories: } 100 \mathrm{mg} \text { daily at night }\end{array}$ \\
\hline Piroxicam & $\begin{array}{l}\text { GIT: Gastric erosion , peptic ulceration } \\
\text { Hypersensitivity reactions: Skin rashes, pruritus and } \\
\text { angioedema } \\
\text { Renal toxicity }\end{array}$ & $\begin{array}{l}\text { Tablets } \\
\text { Topical Gel }\end{array}$ & $\begin{array}{l}40 \mathrm{mg} \text { daily for the first two days then } \\
20 \mathrm{mg} \text { daily for up to } 14 \text { days }\end{array}$ \\
\hline Naproxen & $\begin{array}{l}\text { GIT: Gastric erosion , peptic ulceration } \\
\text { Hypersensitivity reactions: Skin rashes, pruritus and } \\
\text { angioedema } \\
\text { Renal toxicity }\end{array}$ & Tablets & $\begin{array}{l}500 \mathrm{mg} \text { initially then } 250 \mathrm{mg} \text { 8hourly } \\
\text { Maximum: } 1 \mathrm{~g} / \text { day }\end{array}$ \\
\hline $\begin{array}{l}\text { Mefenamic } \\
\text { Acid }\end{array}$ & $\begin{array}{l}\text { Stomach aches, GIT: nausea, vomiting, constipation, heartburn. } \\
\text { CNS: dizziness }\end{array}$ & $\begin{array}{l}\text { Oral syrups } \\
\text { Tablets }\end{array}$ & $\begin{array}{l}500 \text { mg } 8 \text { hourly for a Maximum of } 5 \\
\text { days }\end{array}$ \\
\hline Celecoxib & $\begin{array}{l}\text { weakness, shortness breath, chest pain, visual and balance } \\
\text { impairment, slurred speech, tarry stools }\end{array}$ & $\begin{array}{l}\text { Tablets } \\
\text { Capsules }\end{array}$ & $\begin{array}{l}100-200 \mathrm{mg} 12 \text { hourly } \\
\text { Maximum: } 400 \mathrm{mg} / \text { day }\end{array}$ \\
\hline Etoricoxib & $\begin{array}{l}\text { GIT: Nausea, dyspepsia, diarrhoea, flatulence } \\
\text { Steven-Johnsons Syndrome } \\
\text { Hypersensitivity reaction: Toxic epidermal necrolysis } \\
\text { Renal toxicity }\end{array}$ & $\begin{array}{l}\text { Tablets } \\
\text { Capsules }\end{array}$ & $60-90 \mathrm{mg}$ daily \\
\hline Meloxicam & $\begin{array}{l}\text { Weakness, shortness breath, chest pain, visual and balance } \\
\text { impairment, slurred speech, tarry stools. }\end{array}$ & $\begin{array}{l}\text { Tablets } \\
\text { Capsules } \\
\text { Suppositories } \\
\text { Intramuscular }\end{array}$ & $\begin{array}{l}\text { Oral: } 7.5-15 \mathrm{mg} \text { daily } \\
\text { Rectal: } 15 \mathrm{mg} \text { daily } \\
\text { IM: } 7.5-15 \mathrm{mg} \text { daily for up to } 3 \text { days. For } \\
\text { elderly dose at } 7.5 \mathrm{mg} \text { daily maximum }\end{array}$ \\
\hline
\end{tabular}


prescribe fentanyl when the use of morphine is contraindicated. Pethidine is not recommended as it is not a good analgesic and when used long-term its metabolite, nor-pethidine, may cause seizures. Each narcotic has different dosages at which they provide analgesia; therefore, dosing should be based on pain severity. Narcotics are generally used as short-term treatment. In cases where it is being used long term, side effects of the narcotics should be taken into consideration. ${ }^{25,26}$

Morphine is the golden standard of strong narcotic treatment. Morphine is available as an immediate-release, prolonged release and an oral solution. Immediate-release formulations are used to individualised patient dosages. Prolonged-release formulations help improve patient compliance to therapy. Oral solutions can be given, if the patient is unable to swallow tablets. ${ }^{26}$

Narcotic analgesics do not exhibit a ceiling effect. It is therefore important to use pain management scales in order to ensure that adequate analgesia is being provided with the least amount of side effects present. Medicines used to treat narcotic overdoses like naloxone should be kept within a healthcare facility in case adverse effects or complications are experienced. ${ }^{23}$

When a patient no longer requires the use of narcotics it should be slowly tapered down. Whilst tapering down the narcotic dosages, it is important to monitor the patient's vital signs and ensure they are pain free. The immediate removal of narcotics can lead to withdrawal symptoms. ${ }^{26}$

\section{Combination narcotic Formulations}

Combination therapy includes the use of one or more narcotic agents and a non-narcotic agent. Combination therapy should be considered when pain management is not under control. The advantage of using combination therapy is that doses of the medicine are usually lower compared to when it is administered by itself. Combination therapy has proven to be more beneficial than a one agent approach in post-surgical patients. Prescribers and dispensers should always be alert for previous substance abusers or patients who suffer from seizures or are on any antidepressants (SSRIs, MOA inhibitors). ${ }^{27,28}$

In 1986 the World Health Organization (WHO) realised the need for addressing pain management in patients. A simple algorithm was developed for the introduction and titration of pain medication in patients. This later became known as the 'WHO analgesic ladder.29 The ladder consists of 5 recommendations for the correct use of pain medicine ${ }^{24}$ :

- The oral route should be used whenever possible

- The dosing interval should be individualised depending on how much pain the patient is in and agents' duration off efficacy.

- Medication should only be prescribed once the patient has received a clinical examination. As such, the way the patient feels is taken into consideration.

- Individualized dosages should be used. Every patient will perceive pain differently, thus dosages should be adjusted according to the level of pain the patient is experiencing.

- Compliance to pain medicine is crucial for pain management. Thus patients or their caregivers/family members should understand the type of medicine they are on and how to administer it.

\section{Muscle Relaxants}

Muscle relaxants are reserved for when conventional analgesia does not supress pain adequately. Muscle relaxants act by relieving muscle spasm and thereby relieving pain and discomfort. ${ }^{31}$

Muscle relaxants can be classified in two categories depending on their mechanism of action:

- Antispasmodics - act by relieving muscle spasms through alteration in central nervous system conduction.

- Antispastics - act by relieving hypertonicity and muscle spasms by either acting directly on the muscle or on the spinal cord.

\section{Conclusion}

Sport injuries either caused by over exertion or trauma lead to discomfort and may affect day-to-day activities. There are many treatment modalities available; however, choosing a treatment approach should be dependent on a physical exam, the type of sports injury or muscle injury and the patient's compliance to the treatment regimen. Combination therapy should be

Table 7: Formulations, receptors and doses of opioids

\begin{tabular}{|c|c|c|c|}
\hline Types & Dosage forms & Receptor activity & Doses \\
\hline Morphine & $\begin{array}{l}\text { Tablets } \\
\text { Intravascular injection } \\
\text { Subdermal patch } \\
\text { Oral syrup }\end{array}$ & mu-( $\mu$ ) and kappa-(k) opioid receptors & $\begin{array}{l}\text { Oral: } 5-30 \mathrm{mg} \mathrm{3-4hrly} \\
\text { IM 5-10mg 3-4 hourly } \\
\text { IV } 1-2.5 \mathrm{mg} 5-10 \text { mnts up to } 15 \mathrm{mg}\end{array}$ \\
\hline Hydromorphine & Tablets & mu-( $\mu)$ and kappa-(k) opioid receptors & 4-8mg every daily \\
\hline Codeine & $\begin{array}{l}\text { Tablets } \\
\text { Oral syrup }\end{array}$ & $\begin{array}{l}\text { Partial affinity for k-receptors and } \mu \text { receptors, } \\
\text { strong affinity for delta }(\delta) \text { receptor }\end{array}$ & PO 30-60 mg 4-6 hourly \\
\hline Hydrocodone & Tablets & mu- $(\mu)$ and kappa-(k) opioid receptors & 5-10 mg 4-6 hourly \\
\hline Fentanyl & $\begin{array}{l}\text { Intravascular solution } \\
\text { Transdermal Patch }\end{array}$ & mu-(u) receptor & $\begin{array}{l}\text { IV } 25-50 \mathrm{mcg} / \mathrm{hr} \\
\text { IM } 50-100 \mathrm{mcg} / \mathrm{hr} \\
\text { Transdermal } 25 \mathrm{mcg} / \mathrm{h} \text { every } 72 \text { hours }\end{array}$ \\
\hline Methadone & $\begin{array}{l}\text { Oral linctus } \\
\text { intramuscular }\end{array}$ & Delta $(\delta)$ receptor & $\begin{array}{l}\text { PO 10-25 mg 3-4hrly } \\
\text { IM 10-25 mg 8-12 hourly }\end{array}$ \\
\hline
\end{tabular}




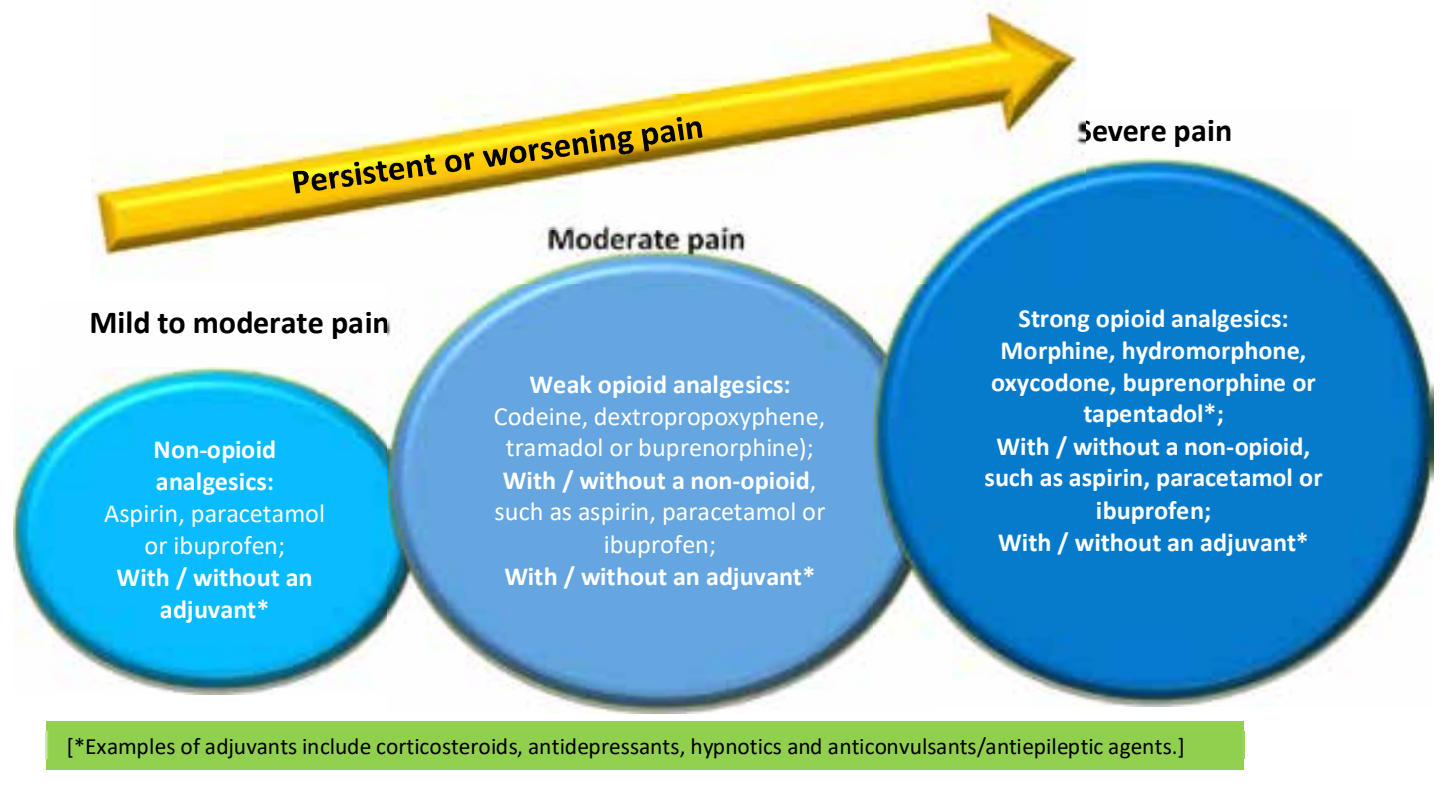

Figure 8: The World Health Organization's three-step analgesic guideline ${ }^{30}$

a golden standard of therapy as most of the medication is synergistic and lower dose of each medicine will be needed to achieve pain relief. Non-pharmacological measures should also be emphasised when speaking to the patient because they are cost effective and can be used multiple times a day to provide relief from pain and discomfort.

\section{References}

1. Selwood L. Topical treatment for sports injuries. S Afr Pharm J. ;82(7):18-21.

2. Hachigian Gould A. Sports Injuries: Types, Treatments, and Prevention. [Online] OnHealth. [accessed 4 Sep 2017]. Available from: http://www.onhealth.com/ content/1/sports_injuries

3. Lefevre N, Bohu Y, Herman S, Klouche S, Servien E. Major Causes of Sports Injuries.

4. Niams.nih.gov. Handout on Health: Sports Injuries. [Online]. [accessed 28 Aug 2017]Available from: https://www.niams.nih.gov/health_info/ sports_injuries/\#ra_17

5. Peterson L, Renstrom AF. P.A.F.H. Sports Injuries: Prevention, Treatment and Rehabilitation. 4th ed. Sweden: CRC Press. 2016.

6. Summitmedicalgroup.com. Overuse Injuries | Summit Medical Group. [Online]. 2017 [accessed 28 Aug 2017]. Available from: http://www.summitmedicalgroup. com/news/fitness/Overuse-Injuries/.

7. ACSM. [Online]. 2017 [accessed 29 Aug 2017]. Available from: https://www.acsm. org/docs/brochures/sprains-strains-and-tears.pdf

8. Hoffman M. The Seven Most Common Sports Injuries. [Online] WebMD. [accessed 30 Aug 2017].Available from: http://www.webmd.com/men/features/ seven-most-common-sports-injuries\#2

9. Elastoplast.com.au. Sports Injury Management | Elastoplast. [Online] [accessed 30 Aug 2017].Available from: https://www.elastoplast.com.au/ strapping-and-injuries/injury-management-and-prevention/injury-management

10. Harvard Health. Treating sports injuries - Harvard Health. [Online] Harvard Health. [accessed 30 Aug 2017]Available from: https://www.health.harvard.edu/ newsletter_article/treating-sports-injuries.

11. Vance C, Rakel B, Dailey D, Sluka K. Skin impedance is not a factor in transcutaneous electrical nerve stimulation effectiveness. J Pain Res. ;571.

12. Johnson MI. Transcutaneous electrical nerve stimulation (TENS). eLS.

13. Wilkonson J, Falerio R. 2007. Acupuncture in pain management. Continuing education in anaesthesia, critical care and pain. BJA Education. 2007;7(14);135-8.

14. Draper D, Hawkes A, Johnson A, Diede M, Rigby J. Muscle Heating With Megapulse II Shortwave Diathermy and ReBound Diathermy. Journal of Athletic Training. ; 48(4):477-82.

15. Verghese ST, Hannallah RS. Acute Pain Management in Children. J Pain Res. ;3:105-23.

16. Batten G. The Role of Medications in the Treatment of Sports-Related Injuries - Tri-Valley Orthopedic Specialists. [Online] Tri-Valley Orthopedic Specialists. [accessed 30 Aug 2017]Available from: http://www.trivalleyorthopedics.com/ the-role-of-medications-in-the-treatment-of-sports-related-injuries/.

17. The International Consensus Group for Neonatal Pain. New guidelines for management of neonatal pain. Archives of Pediatrics and Adolescent Medicine. ;155(2):173-80.

18. Ottani A, Leone S, Maurizio S, Ferrari A, Bertolini A. The analgesic activity of paracetamol is prevented by the blockade of cannabinoid CB1 receptors. Eur J Pharmacol.;531(1):28081.

19. Cohen LL, Lemanek K, Blount RL, Dahlquist LM, Lim CS, Palermo TM, et al. Evidence- based Assessment of Pediatric Pain. J Pediatric Psychol. ; 10:1093.

20. Zarghi A, Arfaei S. Selective COX-2 Inhibitors: A Review if Their Structure Activity Relationships. IJPR. [accessed on: 13 January 2017];10(4). Available from: <https://www.ncbi.nlm.nih.gov/pmc/articles/PMC3813081/. Chan AT, Dettering E. Prospects For Chemoprevention Of Colorectal Neoplasia. 1st ed. Berlin: Spring.

21. Nhs.uk. (2017). Sports injuries - Treatment - NHS Choices. [Online] 2017 [accessed: 12 Jan 2017]. Available from: http://www.nhs.uk/conditions/Sportsinjuries/Pages/Treatment.aspx WHO guidelines on the pharmacological treatment of persisting pain in children with medical illnesses. 2012. [Homepage on internet]. Available from: http://www.who.int/medicines/areas/ quality_safety/guide_perspainchild/en/

22. Vargas-Schaffer $\mathrm{G}$. Is the WHO analgesic ladder still valid?: Twenty-four years of experience. Canadian Family Physician. ;56(6):514-17.

23. Bouwmeester J, Van Dijk M, Tibboel D. Human neonates and pain. In: Hendriksen CFM, Morton DB, eds. Humane endpoints in animal experiments for biomedical research. London: Royal society of medicine press.

24. Palermo TM, Valrie CR, Karlson CW. Family and Parent Influences on Pediatric Chronic Pain. American psychological Association. Department of Anesthesiology and Pain Medicine, University of Washington and Center for Child Health, Behaviour and Development, Seattle Children's Research Institute, Seattle, Washington. 2014;69(2):142-52.

25. Park HJ, Dong EM. Pharmacologic Management Of Chronic Pain. Korean J Pain. ;23(2):99-108.

26. Blondell RD, Azadfard M, Wisnieeski A. Pharmacologic therapy for acute pain. American Academy of Family Physicians. ;87(11):765-72.

27. Ballantyne J, Kalso E, Stannard C. WHO analgesic ladder: a good concept gone astray. BMJ.;i20.

28. Baumann TJ, Herndon CM, Strickland JM. Chapter 44. Pain Management. In: DiPiro JT, Talbert RL, Yee GC, Matzke GR, Wells BG, Posey L. eds. Pharmacotherapy: A Pathophysiologic Approach, 9e. New York, NY: McGraw-Hill. 2014 [a13 ]. Available from: http://accesspharmacy.mhmedical.com/content. aspx?bookid $=689 \&$ Sectionid $=45310494$

29. Witenko C, Mooman-Li R, Motycka C, Duane K, Hincapie-Castillo J, Leonard P, et al. Considerations for the appropriate ase of skeletal muscle relaxants for the management of acute low back pain. Pharm Ther. ;39(6):427-35. 